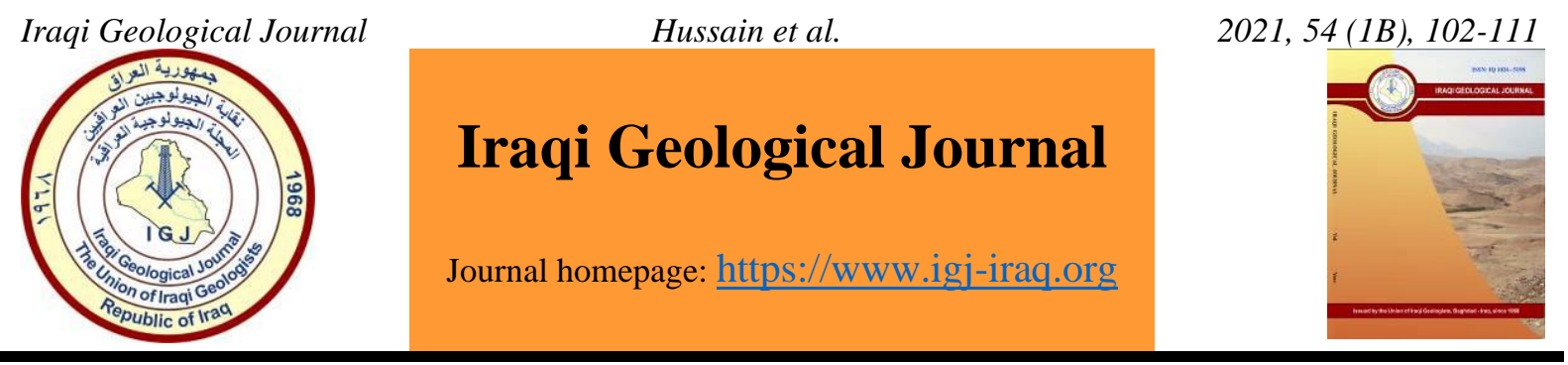

\title{
Microfacies Characterizations and Paleoenvironment of Upper Part of Qamchuqa Formation from Chwarqauran Section, Sulaimaniyia Area, Kurdistan Region, Iraq
}

\author{
Salah A. Hussain ${ }^{1, *}$, Abdalratha M. Sahaab ${ }^{1}$, Khaldoun I. Ahmad ${ }^{2}$, Israa Q. Hussain ${ }^{1}$ and Sarah $^{2}$ \\ A. Hashem ${ }^{1}$ \\ ${ }^{1}$ Department of Petroleum Geology and Minerals, College of Science, University of Diyala, Diyala, Iraq \\ ${ }^{2}$ Liberal Art \& Science, Saint Cloud Technical \& Community College, Minnesota, USA. \\ *Correspondence: salahpgm1977@gmail.com
}

Received: 16 July 2020; Accepted: 26 December 2020; Published :28 February 2021

\begin{abstract}
The Qamchuqa Formation was studied in Chwarqauran section, Sulaimanyia, Kurdistan region, Northeastern Iraq. The lithology of the formation contains limestone throughout the whole section except for one bed of dolomite at the Middle part. Twenty-four slides were prepared from 24 rock samples that were taken from this section to discriminate the petrography and fossil content. The petrographic study shows four main microfacies including lime mudstone, wackestone, packstone, and floatstone. Additionally, there are four sub microfacies: bioclast wackestone, miliolid wackestone, bioclast packstone and orbitolinid packstone. However, the fossil content shows the abundance of benthic foraminifera against the planktonic. All the microfacies indicate facies zone 7, 8 and 9A which reflect deposition in the platform interior between the tidal flat to the mid ramp and back reef environment.
\end{abstract}

Keywords: Qamchuqa Formation; Chwarqauran; Albian; Microfacies; Kurdistan; Iraq

\section{Introduction}

Wetzel (1950) was the first to describe the Qamchuqa Formation in the Qamchuqa gorge in the High Folded Zone in the north and northwestern city of Sulaimanyia, northeastern Iraq. Recent oil exploration in Kurdistan region (N Iraq) show that interest is increasing towards High Folded Thrust Zone (HFTZ), in oil production from those units (Lawa et al. 2020). The formation is underlined (in the type section) by the Sarmord Formation with conformable and gradation contact, while the upper contact with Kometan Formation is an erosional unconformity but without angular discordance (Bellen et al. 1959). Al-Sadooni (1978) studied the sedimentology and petroleum prospects of the Qamchuqa Group from Kirkuk, Bai Hassan and Jambur oil fields and compared the stratigraphy with outcrops at SafeenDagh and inferred that the deposition of the Qamchuqa Group is a rudist-algal-hydrozoans bank (not a reef), he also mentioned that the contact between the Mauddud Formation (The equivalent of the upper Qamchuqa Formation) and the overlying Dokan Formation is unconformable. Ameen (2008) studied the sedimentology and lithostratigraphy of the Qamchuqa Formation, along the outcrop section in northeastern Iraq and subdivided the formation into eight units based on the lithology and fossil content, concluding that the formation was deposited in low energy reef, back-reef, fore-reef and lagoon environments. Gharib (2009) recorded nine facies associations from the Cretaceous sequence of the DOI: 10.46717 /igj.54.1B.9Ms-2021-02-27 
Qamchuqa Formation that includes the inner, middle and outer ramp with supratidal facies associations to the outer ramp. The inner ramp consists of massive limestone at lime wackestone and lime packstone rich with benthonic foraminifera like Orbitolina spp., Pseudocyclammina spp., Pseudochrysalidina spp., Trocholina spp., Cuneolina spp., Textularia sp, Ovalveolina with pelecypod in the lower limestone unit in the Qamchuqa section. Miliolids also form the deposits within the inner ramp in the upper limestone unit in all sections at lime wackestone and lime packstone microfacies. Supra tidal that represents the stromatolite in the upper limestone unit in the Safin section also was within the inner ramp. The middle ramp consists of well-bedded limestone with interbedded thin marl in the middle limestone unit in the Qamchuqa and Smaqwly sections characterized by calcareous algae of green and red algae at lime wackestone to lime packstone microfacies, also other associations indicate the middle ramp consists of massive limestone, rich with rudist in the upper limestone unit in all sections at the lime rudstone microfacies while the outer ramp includes the massive limestone-rich with Orbitolina in the upper limestone unit in all sections at the lime wackestone and lime packstone microfacies. According to Al-Zaidy (2010), the Qamchuqa Formation is subdivided into six main paleoenvironments. These are the shallow restricted, shallow semi-restricted, shallow open marine, shoal, deep outer ramp and deep basinal environments. He also stated that the studied succession represents the deposition of four third order cycles.

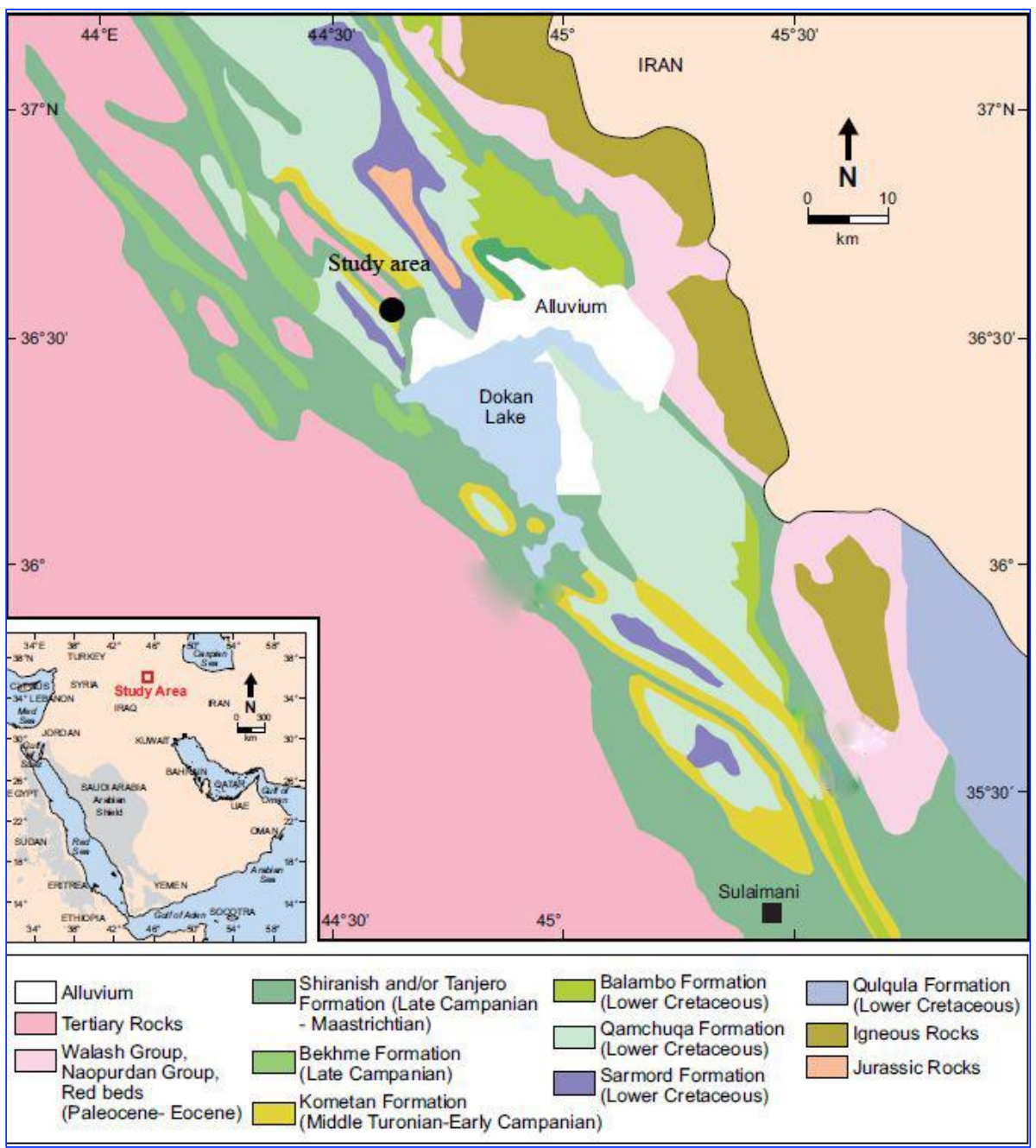

Fig. 1. Location map of the study area (re-drawn from Jaff et al, 2014) 
These cycles were deposited during successive episodes of relative sea-level rises and still stand. Lawa and Gharib (2014) studied the Tethyan Cretaceous successions from the northwestern Zagros fold-thrust belt in the Kurdistan region, NE Iraq and revealed eight benthonic zones from the Qamchuqa Formation (Barremian to Lower Early Cenomanian). Al-Bayati and Al-Banna (2015) studied the Qamchuqa Formation based on two surface sections in the Bekhme and Galala areas in the Kurdistan region, NIraq. They recognized that Qamchuqa rocks are characterized by their hard and high porosities and formed of dolostone, limestone and dolomitic limestone. The formation sequences are composed of lithofacies. Mamaseni et al. (2019) stated that Qamchuqa Formation at Duhok basin, northern Iraq. is represented by palynofacies six (PF.6), these facies are also a high percentage of phytoclasts content but more than PF.5, which the range is $48-85 \%$ with a moderate percentage of palynomorphs $(12-43 \%)$ and a low percentage of amorphous organic matter $(3-15 \%)$. The Qamchuqa Formation was deposited under proximal oxic shelf (III) condition. In the present study, the formation is of three main sedimentary facies. Limestone facies consist of four microfacies, dolostone microfacies are subdivided into five submicrofacies and lithofacies are subdivided into two studied in the Chwarqurna area, located with the Sulaimanyia, Kurdistan region, northeastern Iraq. This work aims to study the microfacies analysis and paleoenvironment of the only cropped out part of the Upper Qamchuqa Formation. The site of the work is located in northeastern Iraq, Sulaimanyia (Fig. 1). The coordinate of the section is $36^{\circ} 12^{\prime} 41^{\prime \prime} \mathrm{N}, 44^{\circ}$ $50^{\prime} 16^{\prime \prime} \mathrm{E}$.

\section{Materials and Methods}

Twenty-four carbonate rock samples were collected from Chwarqauran section. The thickness of the section is $68.5 \mathrm{~m}$ and the distance between the samples is 1 to $5 \mathrm{~m}$ depending on the bed's characteristics. These samples were used to prepare twenty-four slides in the workshop of the Department of Petroleum Geology and Minerals, College of Science, University of Diyala. In the laboratory a petrographic study was done including microscopic examination of thin sections under a microscope, Leica PN: DM 500, to determine the petrographic characteristics and fossil contents. The slides were photographed using an Optika D9 camera. Finally, Arc GIS, Sedlog and Corel 9 were used to draw the maps, stratigraphic sections and plates.

\section{Results}

Rock bodies with specified characteristics are called facies. Ideally facies are a unit of discriminated rock that are deposited under special condition sedimentation and indicate a specific process of the environment (Reading, 1996). Sedimentary facies associations such as fining and coarsening-upward successions of facies, which indicate shifts in environmental conditions, and fossils which are useful indicators of salinity, temperature, water depths, water energy and turbidity of ancient oceans can be used to construct facies models for each major depositional environment (Boggs, 2009). The lithology, standard microfacies SMF, Facies zone FZ and depositional environment of the studied section are shown in Fig. 2. The depositional environments of the Upper Qamchuqa Formation have been interpreted based on the microfacies characterizations. The microfacies characteristics are clarified by texture, grain size and types (skeletal and non-skeletal). The modified carbonate rocks classification of Dunham (1962) by Embry and Klovan (1971) (Fig. 3) were adopted. The distribution of larger benthic foraminifera of the cretaceous by BouDagher-Fadel (2008) was also used to help discriminate the environment of deposition (Fig. 4). The identified microfacies were compared with the standard microfacies and depositional models of Flugel (2004). The most dominant component in the studied part of the Qamchuqa Formation are represented by the skeletal grains, among them the foraminifera, Ostracods and pelecypods shells are the most common. 


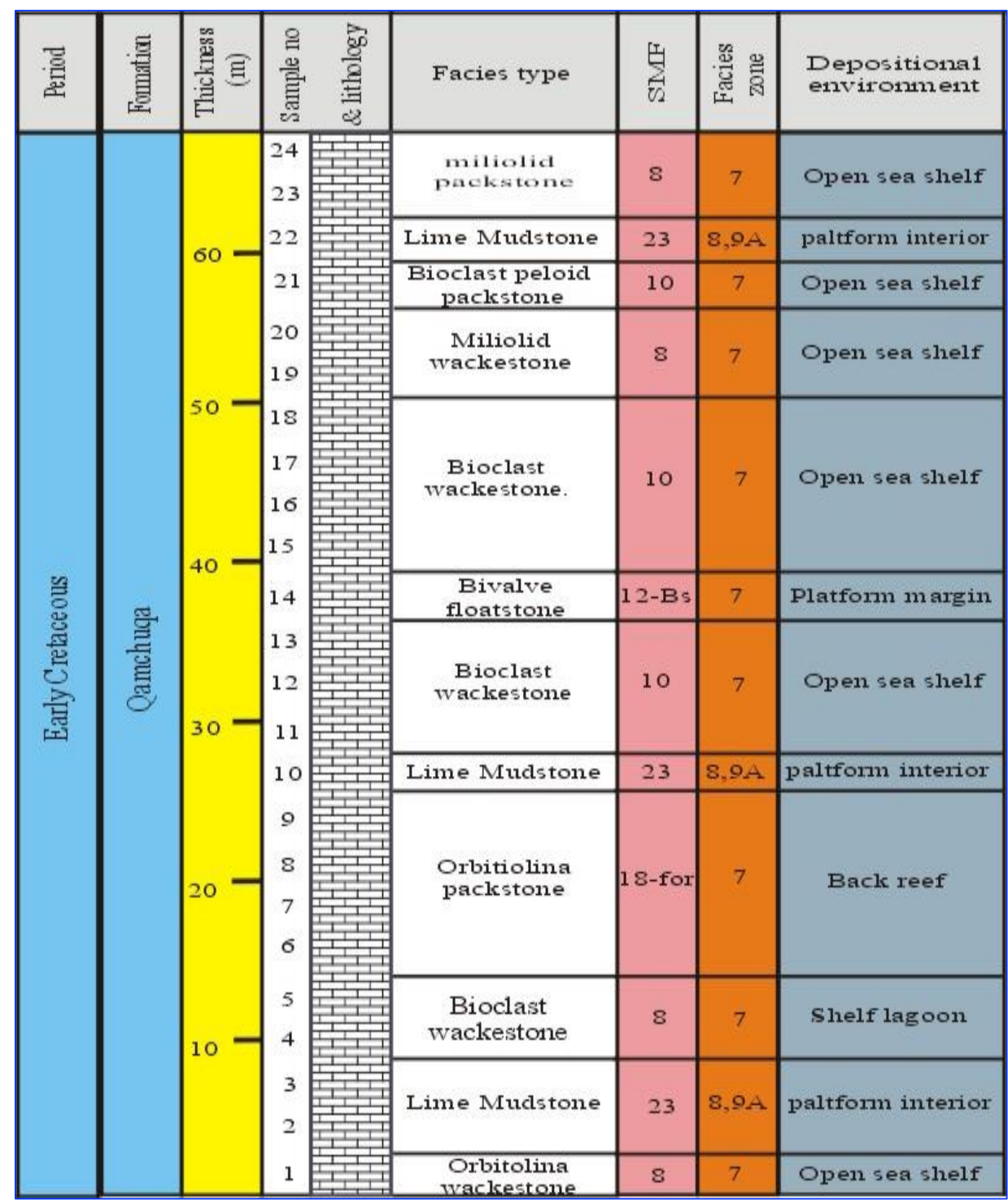

Fig. 2. Standard microfacies SMF, facies zone FZ and paleoenvironment

\subsection{Skeletal Grains}

\subsubsection{Foraminifera}

Foraminifera are single-celled, protists where the cytoplasm is enclosed inside an organic or mineral shell called tests. The shells are composed of single or multi chambers (Sen Gupta, 1999). The result of microfacies is interpreting the depositional environment and they are common and widely distributed in present seas (Hemleben et al. 1989).

\subsubsection{Benthonic Foraminifera}

Benthonic Foraminifera are very abundant grains in the Qamchuqa Formation indicating a shallow open marine environment, and this abundance reflects shallow, well-lighted, temperate, little nutrition waters and suitable substrate with normal salinity Hottinger (Murray, 1991; O'Connell et al. 2012). There are many types of benthonic forams recognized in the studied sections. These are Orbitolina spp. (Plt.1-A), Miliolids (Plt.1-B), Cuneolina sp. (Plt.1-C) and Nezzazata spp. (Plt. 1-D). 


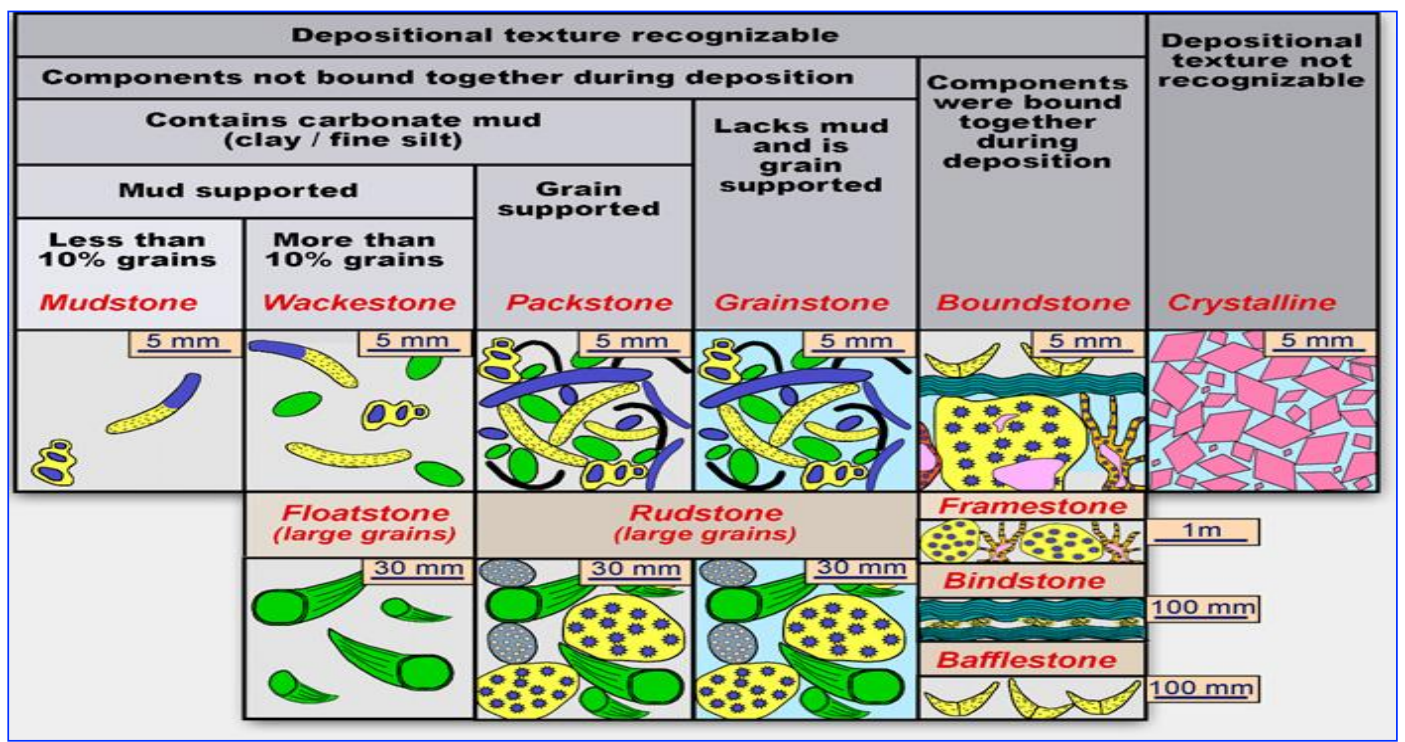

Fig. 3. Modified classification of Dunhum (1962) by Embry and Klovan, 1971

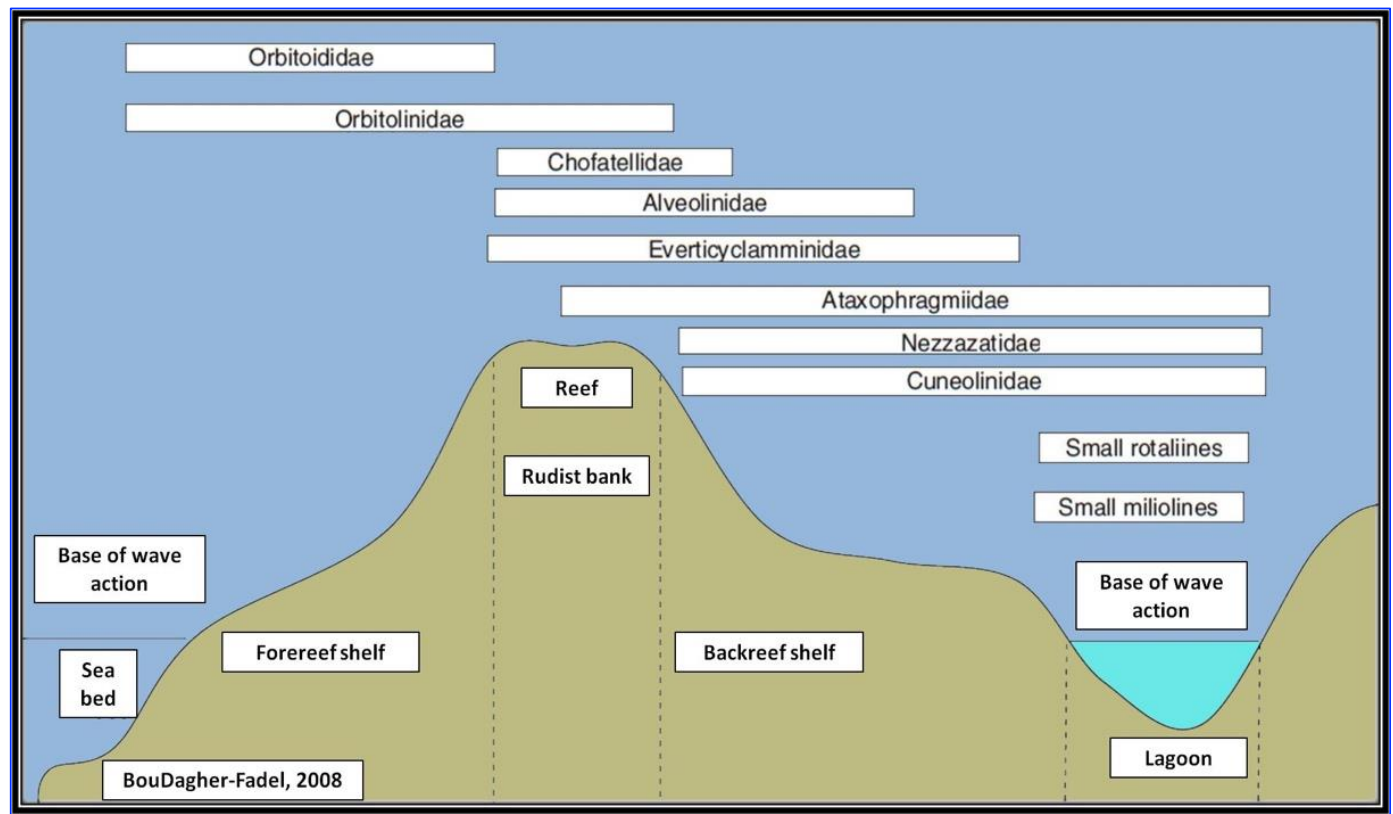

Fig. 4. Distribution of larger benthic foraminifera (BouDagher-Fadel, 2008)

\section{1. 3 Orbitolinids}

Represent the most abundant skeletal grain in the studied section. The Orbitolinids are abundant in the outer platform in shallow deep water. Orbitolinids reproduced toward the open sea of the shallow water at depths of 30 to $80 \mathrm{~m}$ (Gräfe and Wendler, 2003).

\section{1.4 Miliolids}

They are tropical regions with $25^{\circ} \mathrm{C}$ shallow waters and indicate depths of about 33 meters and salinity of 30-50 ppt (Murray, 2006). 


\subsubsection{Planktonic Foraminifera}

In present study it is represented by only Globigerina sp. (Plt. 1-E).

\subsubsection{Bioclasts}

Bioclast is the debris of organisms, resulting from the transmission and robbing of fossils. The bioclast as an expression is applied for fossils under microscope. Fossils are wracked (broken shells) or biomorph (bivalves), and skeletal grain is equivalent to bioclast (Flugel, 2010). The main component of the bioclasts found in this study are clasts of foraminifera, ostracods and shell fragments. The source of these shell bioclasts are due to either trituration by rapacious or operation after animals' death (Ginsburg, 1957; Trewin and Welsh, 1976; Vermeij, 1987), (Plt. 1-F).

\section{1.7. Non- skeletal grains}

These are the grains which are not related to the skeletal components of micro-organisms (Tucker and Wright, 1990). They are less abundant in the Qamchuqa Formation than skeletal grains and represented by peloids and intraclasts.

\subsubsection{Peloids}

Peloids are ovoid, spherical or rod shaped, composed of micrite, without internal structure (Boggs, 2009). Peloids are the most common non-skeletal grain in the Qamchuqa Formation. Their size ranges from silt to sand with ovoid or spherical shape and they are abundant in peri-tidal carbonates waters and deeper water. Peloids are scarce in the polar cooler water carbonates (Flugel, 2004), (Plt.1$\mathrm{G})$.

\subsubsection{Intraclasts}

Intraclasts are lime fragments of consolidated or partly consolidated particles which come from the denudation of closely penecontemporaneous sediment from intraclast, extraclast, and lithoclasts of a basin and reprecipitated inside the same basin. They exist in sholy ecosystem but may move to inward water. The intraclasts are formed in shallow water environments which are distinct by high energy systems and tides which constantly rework lime sediments. Intraclasts are less common than peloids. They represent reworked grains of the Qamchuqa carbonates arising from current agitation. The differences in size, shape and orientation of the Intraclasts, indicate strong reworking of semi-lithified sediment (Flugel, 2010) (Plt.1-H).

\subsection{Microfacies}

Microfacies of present work are subdivided into four main carbonate microfacies and four submicrofacies (Fig. 2).

\subsubsection{Non-fossiliferous lime mudstone microfacies ml}

Characterized by non-laminated homogeneous micrite, these microfacies exist in the lower, middle and upper part of the Upper Qamchuqa Formation. They are equivalent to standard microfacies SMF 2, which are deposited within the facies zone FZ 8 that reflect tidal flats or evaporitic coasts FZ 9A, both of FZ 8 and 9A indicate saline or evaporative environments (Flugel, 2010) (Plt.1-I). 


\subsubsection{Wackestone microfacies}

These contain two submicrofacies:

\subsubsection{Bioclast wackestone submicrofacies $M 2$}

These contain skeletal and shell fragments consisting of more than $15 \%$ of the total components of the facies. They are represented by small-size shell fragment, as well as a few benthic foraminifera and Ostracoda. All skeletal components fall into a gray-colored micrite; these microfacies exist in the lower and middle part of the Upper Qamchuqa Formation and compared with SMF 10 and deposition in the FZ 7 which represent inner and mid-ramp settings. (Wilson, 1975; Flugel, 2010) (Plt.1-J).

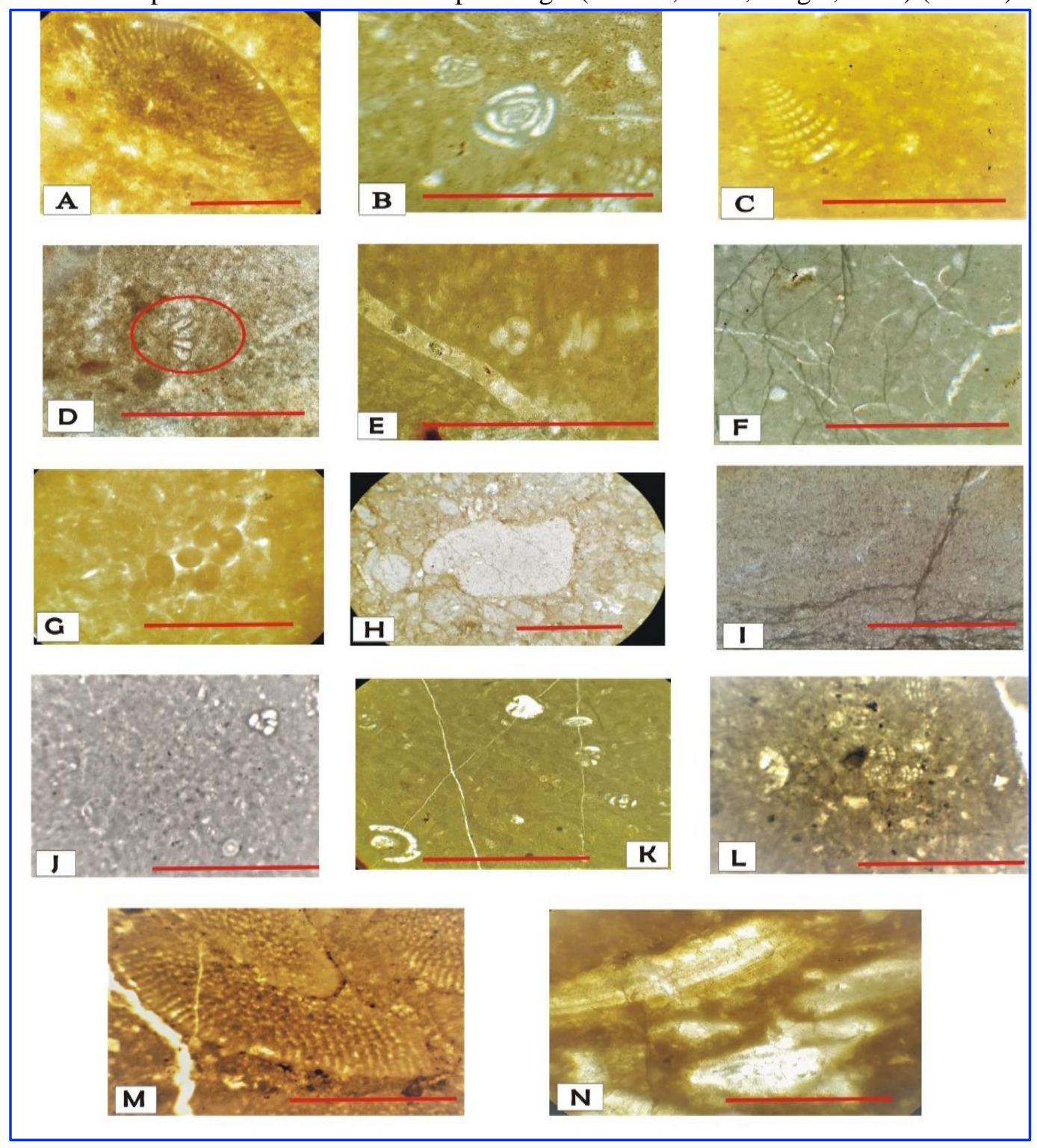

Scale bar: 1000 micron

Plate 1. (A) Orbitolina sp; (B) Miliolids; (C) Cuneolina; (D) Nezzazata; (E) Globigerina; (F) Shell fragments; (G) peloids; (H) intraclasts; (I) non-fossiliferous lime mudstone M1; (J) Bioclast wackestone submicrofacies M2; (K) Miliolid wackestone submicrofacies M3; (L) bioclast packstone submicrofacies M4; (M) Orbitolina packstone submicrofacies M5; (N) Bivalve floatstone microfacies M6. 


\subsubsection{Miliolid wackestone submicrofacies M3}

Characterized by the presence of miliolid and other benthic and planktonic foraminifera (orbitolinids, miliolids) and Ostracoda, these microfacies are found in the upper part of the Upper Qamchuqa Formation and they can be compared with SMF 8 and FZ 7 which reflect shelf lagoon with circulation (Plt.1-K).

\subsubsection{Bioclast packstone submicrofacies $M 4$}

These are characterized by skeletal and non-skeletal components in the rate of 50\%, containing benthic foraminifera with coarse and fine peloids. These microfacies exist in the upper part of the Upper Qamchuqa Formation and can be compared with standard microfacies SMF 10 and deposition in the facies zone FZ- 7 which represent inner and mid-ramp settings. (Wilson, 1975; Flugel, 2010) (Plt.1-L).

\subsubsection{Orbitolina packstone submicrofacies M5}

Consisting of a high abundance of benthic foraminifera (Orbitiolina spp.) and few shell fragments, these microfacies exist in the lower part of the Upper Qamchuqa Formation and can be compared with SMF (18-for) and deposition in FZ 7 which reflect lagoon environment (Wilson, 1975; Flugel, 2010) and also can be deposited in back reef environment according to the model of the special distribution of the Cretaceous larger benthic foraminifera along the shelf of Tethys (BouDagher-Fadel, 2008) (Plt.1-M).

\subsubsection{Bivalve floatstone microfacies M6}

Characterized by the dominance of non-attached bivalve shells arranged in a parallel pattern with micritic supported background, this microfacies exists in the middle part of the Upper Qamchuqa Formation and can be compared with the standard microfacies SMF (12-Bs) and deposition in the facies zone FZ 7 (Plt.1-N).

\subsection{Paleoenvironment}

Using the model of benthic forams of Cretaceous by BouDagher-Fadel (2008) which depends on index fossils (benthic forams) distribution (Fig. 4) found in the succession, some of these benthic forams prefer the platform ecosystem like Orbitolina spp., which indicates back-reef towards the open sea. Miliolids reflect shallow shelf environment, Cuneolina sp., and Nezzazata spp., occupying the total shelf to the back-reef; all these benthic forams indicate a shallow open marine environment (Hottinger, 1983; Murray, 1991; O'Connell et al., 2012). The standard microfacies by Flugel (2010) and facies zones by Wilson (1975) which inferred from microfacies of the studied section discriminate shallow waters of the interior platform from the evaporitic or brackish water FZ 9A to back-reef FZ 7.

\section{Conclusions}

- Four main microfacies were found. These are non-fossiliferous lime mudstone M1, wackestone, packstone and floatstone M6 and four sub microfacies, bioclast wackestone M2, miliolid wackestone M3, bioclast packstone M4 and orbitolinid packstone M5, and these microfacies are sometimes repeated in the section. All microfacies and the fossil distribution reflect the facies zone 7, 8 and 9A.

- The Qamchuqa Formation in the present study was deposited in the platform interior between the tidal flat to the mid ramp and back reef environment. 


\section{Acknowledgements}

Thanks to the Department of Petroleum Geology and Minerals, College of Science, University of Diyala for their help during this study. Sincere thanks to Dr. Mazin Tamer-Agha, Dr. Saad Al-Sheikhly, and Dr. Maher Mahdi for guiding and helping in collecting the samples. Thanks to Melissa Lindsey, The Dean of Arts and Sciences, at Saint Cloud and Technical College, for intensive editing work and proofreading. The authors are very grateful to the Editor in Chief Prof. Dr. Salih M. Awadh, the Secretary of the Journal, Mr. Samir R. Hijab. and the Technical Editors for their great efforts and valuable comments.

\section{References}

Al-Bayati, Z.A.H., Al-Banna, A.Y., 2015. Study of sedimentary facies and depositional environment in Qamchuqa Formation at Northern Iraq. Kirkuk University, Journal for Scientific Studies 11(2), 145-167.

Al-Sadooni, F. R., 1978. The Sedimentology of the Qamchuqa Formation, Northern Iraq, Unpublished Ph.D. Thesis, University of Bristol, $424 \mathrm{P}$.

Al-Zaidy, A. A., 2010. Basin Development and Reservoir Charaterization of the Qamchuaq Formation, NE Iraq, Unpublished Ph.D. Thesis, University of Baghdad, 180 P.

Ameen, B. M., 2008. Sedimentary and Lithostratigraphy of Qamchuqa Formation from Kurdistan Region, NEIraq. Unupublished Ph. D. Thesis, University of Sulaimaniya.

Ameen, F. A., 2014. Biostratigraphy of the Tethyan cretaceous successions from northwestern Zagros fold-thrust belt, Kurdistan region, NE Iraq. Arabian Journal of Geosciences 7(7), 2689-2710.

Bellen, R. C., Van, Dunnington, H. V., Wetzel, R., Morton, D.,1959. Lexique Stratigraphique International. Asie, Iraq, 3(10a).

Boggs, S. Jr., 2009. Petrology of Sedimentary Rocks. Published in the United States of America by Cambrige University press, Newyork.

BouDagher-Fadel, M. K., 2008. Evolution and Geological Significance of Larger Benthic Foraminifera, Elsevier.

Dunham, R. J., 1962. Classification of carbonate rocks according to depositional texture: American Association of Petroleum Geologists Memoir 1, 108-121.

Embry, A. F., Klovan, J. E., 1971. A late Devonian reef tract on northeastern Banks Island. N.W.T., Bulletin Canadian Petroleum Geology 19, 730-781.

Flugel, E., 2004. Micrfacies of Carbonate Rocks, Analyasis Interpertation and Appliaction, Springer.

Flugel, E., 2010. Micrfacies of Carbonate Rocks, Analyasis Interpertation and Appliaction, 2nd edition, Springer.

Ginsburg, R. N., 1957. Early diagenesis and lithification of shallow-water carbonate sediments in South Florida. In: Leblanc, R.J. \& Breeding, J.G. (eds) Regional Aspects of Carbonate Deposition. Society of Economic Paleontologists and Mineralogists, Special Publications 5, 80-98.

Gräfe, K. U., Wendler J., 2003. Foraminifers and calcareous dinoflagellate cysts as proxies for deciphering sequence stratigraphy, sea-level change, and paleoceanography of Cenomanian-Turonian hemipelagic sediments in Western Europe. SEPM, Special Publication 75, "Proxies and sea-level changes" (eds. Mark Leckie, H. Clement Olson), 229-262.

Hemleben, C., Spindler M., Anderson O. R.,1989. Modern Planktonic Foraminifera, Springer-Verlag, BerlinHeidelberg-New York.

Hottinger, L., 1983. Processes determining the distribution of larger foraminifera in space and time. Utrecht Micropaleontological Bulletins 30, 239-253.

Jaff, R. B. N., William, M. S. I., Lawa, F. A., Lee, S., Jan, A., 2014. A refined foraminiferal biostratigraphy for the Late Campanian-Early Maastrichtian succession of northeast Iraq. GeoArabia 19(1), 161-180.

Lawa, F. A., Qadeer, B. O., Fattah, A. I., 2020. Biostratigraphic analysis of the Oligocene-Early Miocene successions from Sulaimani area, Kurdistan Region, Iraq. Iraqi Geological Journal 53 (2D), 19-41.

Mamaseni, W. J., Naqshabandi, S. F., Al-Jaboury, F., 2019. Playnofacies and plaeoenvironment of Late JurassicEarly Cretaceous formations at Duhok basin, Northern Iraq. Iraqi Geological Journal 52(1), 61-82.

Murray, J. W., 1991. Ecology and Paleontology of Benthic Foraminifera. Longman Group, UK.

Murray, J. W., 2006. Ecology and Applications of Benthic Foraminifera. Cambridge University Press, Cambridge. 
O’Connell, L. G., James, N. P., Bone, Y., 2012. The Miocene Nullarbor limestone, Southern Australia; deposition on a vast subtropical epeiric platform. Sedimentary Geology (253-254), 1-16.

Reading, H. G., 1996. Sedimentary Environments: Processes, Facies and Stratigraphy. Third edition. Blackwell, Oxford.

Sen Gupta, B. K., 1999. Introduction to Modern Foraminifera, in Sen Gupta B.K., Ed., Modern Foraminifera, Kluwer, Dordrecht, 3-6.

Trewin, N. H., Welsh, W., 1976. Formation and composition of a graded estuarine shell bed. Palaeogeography, Palaeoclimatology, Palaeoecology 19, 219-230.

Tucker, M. E., Wright, V.P., 1990. Carbonate Sedimentology, Black Wells,

Vermeij, G. J. 1987. Evolution and Escalation: An Ecological History of Life. Princeton University Press, Princeton, NJ.

Wilson, J. D., 1975. Carbonate Facies in Geologic History, Springer verlag, New York. 